\title{
PENGARUH EROPA \\ TERHADAP ARSITEKTUR MASJID RAO RAO TANAH DATAR
}

\section{EUROPEAN INFLUENCE TO THE ARCHITECTURE OF RAO-RAO MOSQUE TANAH DATAR}

\author{
Syahrul Rahmat \\ Universitas Islam Negeri Imam Bonjol Padang \\ Kampus Lubuk Lintah, Padang \\ E-mail: syahrul28@gmail.com \\ Naskah diterima 30 April 2018, diterima setelah perbaikan 20 Mei 2018, \\ disetujui untuk dicetak 31 Mei 2018
}

\begin{abstract}
Abstrak
Masuknya Belanda ke pedalaman Minangkabau pada pertengahan abad IX M memberikan pengaruh terhadap tatanan kehidupan masyarakat, termasuk pengaruh dalam hal pola pikir. Pengaruh tersebut dapat dilihat dari ide-ide yang kemudian diwujudkan ke dalam bentuk benda atau bangunan, salah satunya adalah masjid Rao Rao. Pada dasarnya masjid merupakan bangunan sakral bagi umat Islam, akan tetapi dalam perkembangannya masjid tersebut mendapat pengaruh kebudayaan asing dari segi arsitektur bangunan. Penelitian ini merupakan penelitian sejarah dengan menggunakan pendekatan teori akulturasi guna melihat perpaduan dua kebudayaan pada masjid yang dibangun pada awal abad XX M. Beberapa pengaruh Eropa yang berakulturasi dalam masjid ini meliputi penggunaan material bangunan, unsur-unsur bangunan serta ornamen bangunan masjid.
\end{abstract}

Kata Kunci: Masjid, akulturasi, arsitektur, Eropa, Minangkabau

\begin{abstract}
The coming of the Dutch into Minangkabau inland in the middle of IX century AD gave influence to the order of community's life, including the mindset. The influence can be seen from the ideas that are manifested into the form of objects or building. One of them is the mosque of Rao Rao. Basically, the mosque is a sacred building for Muslims. But in its development, the mosque was influenced by foreign culture in terms of building architecture. This study is a historical research by using the approach of acculturation theory to see the blend of two cultures in the mosque built in the early XX century AD. Some of European influences that acculturate in this mosque include the use of building materials, building elements and mosque building ornaments.
\end{abstract}

Keywords: mosque, acculturation, architecture, Europe, Minangkabau 


\section{PENDAHULUAN}

Keberadaan masjid di Minangkabau memiliki arti penting bagi masyarakat. Masjid tidak hanya difungsikan sebagai sarana dalam melakukan peribadatan, akan tetapi juga sebagai tempat untuk membicarakan persoalan-persoalan yang ada di tengah masyarakat. Posisi masjid di Minangkabau termasuk dalam susunan UU Nagari. ${ }^{1}$ Dalam undang-undang yang mengatur persyaratan tentang kelengkapan sebuah nagari tersebut dinyatakan bahwa sebuah nagari atau kampung hendaklah babalai bamusajik atau memiliki balai dan masjid (Navis, 1984:92).

Memasuki abad XX M, Belanda mulai masuk ke pedalaman Minangkabau dalam bentuk kolonialisasi. Pada 10 Februari 1821, sebuah perjanjian yang melibatkan Belanda dan kaum Minangkabau ditandatangani dengan Sultan Alam Bagagarsyah sebagai pihak yang mengatasnamakan perwakilan Minangkabau (Amran, 1981:407). Perjanjian ini kemudian menjadi alasan yang kuat bagi Belanda untuk masuk ke pedalaman Minangkabau.

Berada di pedalaman Minangkabau, Belanda tidak hanya mempengaruhi tatanan sosial yang ada di tengah-tengah masyarakat. Akan tetapi juga mulai mempengaruhi kebudayaan masyarakat lokal. Salah satu pengaruh tersebut terlihat dari arsitektur. Beberapa bangunan yang ada masa itu sudah dibangun dengan mengadopsi gaya arsitektur Eropa.

Islam sebagai agama yang dianut oleh masyarakat saat itu juga mulai mengalami perkembangan yang diiringi dengan pendirian sarana maupun prasarana penunjang peribadatan. Pada periode awal perkembangan Islam tersebut, material yang digunakan dalam pembangunan masjid merupakan bahan yang berasal dari alam. Periodesasi dari masa ini berlangsung lebih kurang hingga akhir abad XX M.

Memasuki abad XX M, beberapa masjid yang didirikan pada umumnya sudah mulai menggunakan beton atau kapur sebagai bahan bangunan. Sementara pada periode sebelumnya kayu adalah bahan utama yang digunakan dalam pembangunan. Pembangunan masjid pada masa ini tidak hanya sebatas pada peralihan penggunaan bahan, akan tetapi juga mengalami perubahan bentuk arsitektur. Sekali pun tidak ada perubahan secara dominan, akan tetapi terdapat pengaruh asing yang ikut masuk dalam arsitektur bangunanannya.

Masjid Rao Rao Tanah Datar yang dibangun pada awal abaD XX M atau tepatnya pada tahun 1918 memiliki beberapa keunikan dari segi arsitektur. Beberapa bagian masjid ini sudah dipengaruhi oleh beberapa budaya asing yang saat itu telah menyentuh Minangkabau, seperti Hindu Budha, Cina dan Belanda (Sudarman, 2014:76). Pengaruh tersebut dapat terlihat dari arsitektur secara umum serta ornamen-ornamen yang tersebar di seluruh bangunan masjid.

Masjid ini merupakan salah satu bentuk kebudayaan manusia yang diaktualisasikan dalam bentuk benda. ${ }^{2}$ Masjid Rao Rao dapat dikatakan sebagai sebuah bentuk buah dari ide yang ada

\footnotetext{
${ }^{1}$ Delapan pasal yang terdapat dalam Undang-undang Nagari ialah Babalai bamusajik (memiliki balai dan masjid), Basuku banagari (memiliki suku dan nagari), Bakorong bakampuang (memiliki korong dan kampung), Bahuma babendang (memiliki huma atau hunian dan bendang), Balabuah batapian (memiliki labuah atau jalan dan tepian), Basawah baladang (memiliki sawah dan ladang), Bahalaman bapamedanan (memiliki halaman dan medan atau lapangan) serta Bapandam bapusaro (memilik area pemakaman).

${ }^{2}$ Tiga wujud kebudayaan yang dimaksud adalah sebagai sesuatu yang kompleks dari ide-ide, gagasan, nilainilai, norma-norma maupun peraturan. Selanjutnya adalah sebagai suatu kompleks aktivitas serta tindakan berpola dari manusia dan masyarakat serta sebagai benda hasil karya manusia.
} 
pada masyarakat saat itu. Benda sebagai objek kebudayaan merupakan wujud dari masyarakat pada masa tertentu. Oleh karenanya ketika membahas masjid, maka kita juga membahas manusia yang terlibat dalam pembangunan masjid.

Lebih lanjut, Clifford Geertz menilai kebudayaan sebagai pola makna-makna atau ideide yang termuat dalam simbol-simbol. Melalui simbol-simbol tersebut kemudian masyarakat menjalani pengetahuan tentang kehidupan serta mengekspresikan kesadaran (Gerrtz, 1983:87). Melalui simbol, lebih jauh Geertz menilai terdapat hubungan yang saling berkesinambungan antara budaya dan agama.

Masjid Rao Rao sebagai sebuah tinggalan budaya dalam bentuk materi tentunya akan meninggalkan simbol-simbol sebagai wujud dari tinggalan berupa ide. Keberadaan simbol, baik itu berupa ornamen maupun bagian dari bangunan memiliki nilai penting bagi masyarakat. Selain itu melalui simbol yang terdapat pada sebuah bangunan selanjutnya juga dapat diketahui kebudayaan yang berkembang di sekitar bangunan tersebut.

Selain sebagai sebuah wujud kebudayaan, pada masjid Rao Rao juga telah terjadi proses akulturasi antara satu kebudayaan dengan kebudayaan lainnya. Secara garis besar, selain dari bangunan masjid yang merupakan bentuk kebudayaan Islam terdapat kebudayaan lain yang ikut bercampur dalam arsitektur bangunan. Pada aspek material bangunan, masjid Rao Rao sudah tidak menggunakan kayu sebagai bahan bangunan, melainkan menggunakan material kapur atau semen. Sementara masjid tradisional pada umumnya dibangun dengan mengunakan bahan dari alam berupa kayu. Pada proses akulturasi ini terdapat dua hal yang saling berkaitan antara satu dengan lainnya. Hal yang dimaksud adalah aspek material bangunan serta kebudayaan masyarakat Rao Rao Tanah Datar pada awal abad XX M.

Dalam melihat cerminan kebudayaan yang terdapat pada arsitektur dapat dilakukan dengan pola memperhatikan wujud-rinupanya. ${ }^{3}$ Dalam merancang sebuah bangunan, penghadir atau perancang bangunan tidak serta merta dalam mengerjakannya. Terdapat berbagai macam pertimbangan yang dilakukan sebelum membangun sebuah bangunan. Hal tersebut menjadikan sebuah karya tidak akan hadir dari sebuah kegiatan iseng atau ketidaksengajaan. Bangunan lahir dari sebuah pemikiran yang matang, cita rasa, kesepakatan, norma, seleksi, kreatifitas, kepercayaan serta keyakinan dari penghadirnya (Prijotomo, 2008:13-14).

Adanya pengaruh asing dalam bentuk arsitektur Eropa terhadap bangunan masjid Rao Rao menjadi hal yang menarik untuk diteliti, sebab bagi umat Islam masjid merupakan bangunan sakral yang dipergunakan untuk beribadah. Masuknya beberapa unsur-unsur non-Islam ke dalam bangunannya tidak menjadi persoalan bagi masyarakat saat itu. Sehingga masjid Rao Rao dibangun dengan mengadopsi berbagai bentuk arsitektur asing yang pada dasarnya tidak berkaitan dengan nilai-nilai keislaman.

Permasalahan yang diangkat dari penelitian ini adalah akulturasi budaya pada sebuah objek yang dalam hal ini adalah Masjid Rao Rao. Melalui masjid ini dapat dilihat bagaimana akulturasi terjadi di daerah Tanah Datar sehingga berdampak pada bentuk bangunan masjid.

\footnotetext{
${ }^{3}$ Wujud rinupa ialah wujud yang terlihat secara kasat mata, mulai dari bentuk atap, badan dan kaki bangunan, warna maupun tanda-tanda khusus yang terdapat pada sebuah bangunan. Melengkapi rincian dari wujud rinupa tersebut ialah kesan dan suasana yang tertangkap pada wujud tersebut.
} 
Secara lebih spesifik penelitian ini bertujuan untuk menganalisa proses akulturasi di kawasan Tanah Datar serta mengidentifikasi bagian apa saja dari Masjid Rao Rao yang mendapat pengaruh Eropa.

Masjid Rao Rao merupakan satu dari sekian banyak masjid yang dibangun pada permulaan abad XX M. Akan tetapi masjid ini merupakan salah satu masjid yang unik lantaran gaya arsitekturnya yang khas. Sudarman dalam buku Arsitektur Masjid Di Minangkabau Dari Masa Ke Masa juga menjadikan Masjid Rao Rao sebagai salah satu masjid yang mewakili masa peralihan (Sudarman, 2014:4-5). Dalam perspektif keberlanjutan budaya ia menuliskan bahwa masjid yang dibangun pada awal abad XX sudah menggabungkan arsitektur tradisional dan modern.

Sementara itu literatur yang berkaitan dengan akulturasi maupun pengaruh budaya asing terhadap bangunan masjid belum terlalu banyak dijumpai. Beberapa diantaranya baru dalam bentuk tesis atau diterbitkan dalam bentuk artikel. Beberapa penelitian tersebut diantaranya dilakukan oleh Dharmawati Dewi Pamungkas, pada tesis berjudul Seni Rupa Islam Pada Gaya Arsitektur dan Interior Masjid Agung Yogyakarta Awal Abad XX (Pamungkas, 1996: xi). Ia membahas tentang kebudayaan Jawa yang hadir pada setiap desain interior yang ada di dalam bangunan masjid. Selain itu Eddy Hadi Waluyo juga menulis artikel terkait akulturasi yang melibatkan budaya Cina terhadap arsitektur Masjid Kuno di daerah Jawa (Waluyo, 2011). Pada tulisan tersebut ia mengulas akulturasi budaya dalam wujud arsitektur dengan judul artikel Akulturasi Budaya Cina Pada Arsitektur Masjid Kuno Di Jawa Tengah.

\section{METODOLOGI}

Pada dasarnya penelitian ini merupakan penelitian sejarah dengan mengambil batasan temporal pada awal abad XX M dengan mengambil objek masjid kuno yang merupakan salah satu tinggalan cagar budaya. Oleh karenanya metode yang dipergunakan ialah metode penelitian sejarah untuk sumber-sumber yang berhubungan dengan arsip maupun sumber tertulis. Sementara itu untuk masjid yang merupakan objek utama dalam penelitian ini mempergunakan metode penelitian arkeologi.

Beberapa tahapan dalam penelitian sejarah adalah heuristik, kritik sumber, interprestasi dan penulisan (Shamad, 2003:92). Heuristik yang dimaksud disini adalah pengumpulan sumbersumber yang berkaitan dengan kebudayaan masyarakat Minangkabau pada awal abad XX M serta sumber yang berkaitan dengan masjid kuno. Sumber-sumber tersebut bisa berupa arsip, buku maupun foto-foto yang berkaitan dengan masjid Rao Rao. Selanjutnya adalah melakukan kritik terhadap sumber yang telah dikumpulkan, baik itu kritik intern maupun ekstern. Dari beberapa sumber yang telah ada, terdapat perbedaan informasi terkait akulturasi maupun sejarah masjid Rao Rao. Hal inilah yang penulis analisis untuk mendapatkan informasi paling akurat dari informasi-informasi yang telah ada.

Tahap selanjutnya adalah interprestasi, yaitu menformulasikan data yang ada menjadi sebuah rangkaian peristiwa yang terjadi pada awal abad XX M. Dari interprestasi ini nantinya terbentuk sebuah narasi yang membangun suasana pada masa tersebut. Narasi itu tentu berkaitan dengan pembangunan serta penyebab terjadinya akulturasi pada bangunan masjid. Hal terakhir yang dilakukan dalam penelitian ini adalah penulisan ke dalam bentuk karya ilmiah. 
Sementara itu motede penelitian arkeologi yang dilakukan adalah observasi. Beberapa hal yang masuk pada bagian ini adalah mengunjungi objek penelitian guna mengumpulkan data terkait fisik bangunan. Kemudian dilanjutkan dengan pendeskripsian terhadap data-data yang telah terkumpul. Baru setelahnya dilanjutkan dengan eksplanasi serta interprestasi terhadap bagian-bagian yang menjadi fokus penelitian.

\section{PEMBAHASAN}

\section{Bangsa Eropa di Minangkabau dan Pengaruhnya Pada Arsitektur Bangunan}

Hubungan perdagangan antara masyarakat Minangkabau yang ada di kawasan pesisir pantai sudah ada semenjak abad XVII M. Belanda melalui perusahaan dagangnya, Vereenigde Oostindische Compagnie (VOC) merapat pada beberapa wilayah di Sumatera. Kala itu VOC berhenti di kota-kota pelabuhan penting yang memiliki lalu lintas perdagangan cukup sibuk. Beberapa pelabuhan yang disinggahi adalah Indrapura, Pariaman dan Tiku (Amran, 1981:110). ${ }^{4}$

Selain Belanda, pada abad yang sama tepatnya pada tahun 1613 M, Inggris juga berlabuh di beberapa pelabuhan yang ada di perairan Minangkabau dan berhasil melakukan perdagangan di wilayah tersebut. Masa itu terdapat dua kapal Inggris yang berhasil mendapat muatan padat lada di derah Tiku dan Pariaman. Bahkan tidak hanya itu, dua tahun kemudian Inggris mendirikan kantor di daerah tersebut dan berhasil memonopoli perdagangan dari Aceh (Amran, 1981:119120).

Tidak terima dengan keberhasilan Inggris mendirikan perwakilan dagang, Belanda atau VOC yang sebelumnya gagal melakukan perdagang kembali mengirimkan armadanya pada tahun 1615 ke daerah Tiku. Akan tetapi usaha tersebut tetap sia-sia. Setahun kemudian VOC kembali mengirimkan kapalnya ke daerah Inderapura, di daerah ini bertemu dengan Raja Itam. Oleh Raja Itam Belanda dijanjikan lada, akan tetapi ujung-ujungnya tetap tidak membuahkan hasil. ${ }^{5}$

Selanjutnya, kedatangan Belanda dalam bentuk kolonialisasi ke daerah pedalaman Minangkabau baru dimulai pada awal abad IX M. Pada 10 Februari 1821, sebuah perjanjian yang melibatkan Belanda dan masyarakat lokal ditandatangani. Perjanjian tersebut dilakukan antara Belanda dengan kaum Minangkabau yang dilakukan oleh Sultan Alam Bagagarsyah (Amran, 1981:407). Masuknya Belanda ini tidak terlepas dari perang saudara yang terjadi antara kaum adat dan kaum agama atau Paderi. Dari sini kemudian Belanda mulai menduduki wilayah Minangkabau daratan dan mulai menanamkan kekuasaan dan pengaruhnya di tengah-tengah masyarakat.

Setelah jatuhnya Bonjol ke tangan Belanda pada 15 Agustus 1837 di penghujung Perang Paderi, ${ }^{6}$ Belanda mulai menanamkan kekuasaannya di daerah Minangkabau daratan (Dihoeloe, 1939:39-40). Hingga kemerdekaan Indonesia pada tahun 1945, terdapat banyak pengaruh yang ditinggalkan oleh Belanda di daerah Minangkabau. Beberapa pengaruh yang dapat dilihat hingga

\footnotetext{
${ }^{4}$ Pada masa tersebut kedatangan Belanda pada umumnya ditolak oleh pelabuhan yang ada di seluruh Pesisir Pantai Barat Sumatera. Hal itu terjadi lantaran kawasan tersebut berada di bawah kekuasaan Aceh

${ }^{5}$ Perjuangan Belanda untuk dapat memonopoli daerah pesisir pantai Sumatera tidak hanya mendapat hambatan dari sesama pembeli yang datang dari Eropa. Berhadapan dengan rakyat adalah salah satu kesulitan lain yang ditemui oleh VOC. Rakyat Minangkabau yang berhadapan langsung dengan VOC adalah rakyat yang rewel,
} 
saat ini ada dalam bentuk bangunan dengan gaya Eropa, sementara selama kekuasaannya yang diberikan adalah sistem pemerintahan yang diterapkan mengadopsi pemerintahan Belanda (Zulqayyim, 2006:40-41). ${ }^{7}$

Sementara itu bangunan-bangunan yang ada pada masa pendudukan Belanda secara garis besar terbagi dua. Pertama adalah bangunan yang didirikan oleh pendatang yang dalam hal ini adalah Belanda dengan gayanya sendiri. Kedua adalah bangunan bergaya lokal yang didirikan oleh masyarakat lokal (Murtomo, 2008:69) . Konsep ini biasanya digunakan untuk melihat tatanan kota masa kolonial, akan tetapi jika dilihat secara umum yang tidak melibatkan sebuah kota, maka konsep ini masih sesuai dan dapat dikembangkan.

Selama menguasai Indonesia Belanda banyak mendirikan bangunan guna kepentingan umum maupun swasta. Pada tahap-tahap awal pembangunan, baik itu dari bentuk maupun fitur elemen yang dibangun menunjukkan dengan jelas adanya percampuran budaya antara arsitektur Eropa dengan arsitektur tradisional yang ada di Indonesia. Pada tahap ini Belanda mengadopsi elemen tertentu dan fitur arsitektur tradisi arsitektur Indonesia asli ke dalam bentuk bangunan mereka. Sementara elemen arsitektur Eropa dimasukkan ke dalam tradisi arsitektur vernekular Indonesia sehingga nantinya menjadi langgam bangunan kolonial yang disebut dengan arsitektur Hindia Timur atau Indis (Wuisman, 2009:32).

Di Sumatera Barat pun hingga saat ini masih dapat dapat ditemukan bangunan yang dulunya dibangun pada masa pemerintahan Hindia-Belanda. Banyak diantara bangunan tersebut yang sudah tidak murni lagi sebagai bangunan dengan gaya arsitektur asli Belanda. Begitu juga dengan bangunan tradisional atau arsitektur vernekular, sekali pun masih ada yang mempertahankan bentuk tersebut, akan tetapi juga ada beberapa bangunan yang mengadopsi gaya Belanda.

Bangunan rumah gadang di Minang yang dibangun pada masa-masa tersebut sudah ada yang tidak menggunakan bentuk asli sepenuhnya. Pada beberapa daerah yang menjadi pusat pemerintahan Belanda di daerah Minangkabau akan ditemui bangunan rumah gadang yang tidak secara utuh menggunakan bahan kayu. Penggunaan batu atau kapur mulai ditemui pada bagian pondasi serta badan bangunan berupa dinding.

Adanya campur tangan Belanda dalam urusan arsitektur di Minangkabau setidaknya membuat masyarakat mengenal konstruksi bangunan yang lebih kokoh berupa tembok (Sudarman, 2014:98). Sekalipun demikian, untuk rumah gadang yang didirikan pada masa tersebut masih ada yang mempertahankan arsitektur aslinya. Pada periode pendudukan Belanda bahan-bahan juga masih gampang ditemukan sebagai bahan untuk mendirikan bangunan.

sering memberontak, sulit diatur, sehingga segala usaha yang telah dilakukan serasa sia-sia belaka. Perbedaan Minangkabau dengan dengan daerah lain ialah jika di derah lain mereka cukup berhadapan dengan raja atau orang yang paling berkuasa, akan tetapi di Minangkabau Belanda harus berhadapan dengan ratusan penghulu dengan berbagai macam gelar

${ }^{6}$ Pada masa-masa tersebut Tuanku Imam Bonjol terpaksa menyerahkan diri mengingat banyak korban yang jatuh akibat peperangan. Setelah menyerahkan diri, Tuanku Imam Bonjol di bawa ke Bukittinggi, dari Bukittinggi dibawa ke Padang. Dari Padang dengan menggunakan kapal perang ia di bawa ke Betawi dan menetap selama empat bulan. Dari Betawi kemudian diasingkan ke Ambon hingga akhirnya menemui ajalnya di Manado

${ }^{7}$ Selama menduduki Minangkabau, pemerintah Hindia Belanda membagi Minangkabau menjadi dua hoofdafdeeling yang masing-masingnya dipimpin oleh hoofdregent. Kemudian di bawah hoofdafdeeling terdapat regenschapphen dan diikuti oleh kelarasan dan nagari. 


\section{Sejarah Masjid Rao Rao}

Masjid Rao Rao terletak di Jorong Rao Rao, Nagari Rao Rao, Kecamatan Sungai Tarab, Kabupaten Tanah Datar, Sumatera Barat. Bangunan masjid sudah terdata sebagai salah satu tinggalan cagar budaya dengan nomor inventaris 40/BCB-TB/A/12/2007 (Syarif, 2017). Sebelah utara dan barat masjid berbatasan dengan tanah Dt. Sinaro Sati dan di sebelah selatan berbatasan dengan tanah Dt. Malingka sementara sebalah timur masjid berbatasan dengan jalan raya (BP3B: 2007).

Masjid ini didirikan pada sebidang tanah yang sebelumnya di kawasan tersebut sudah berdiri sebuah bangunan surau yang bernama Surau Luhak. Posisi surau tersebut berada di sisi utara masjid saat ini. Lokasi tempat didirikannya Masjid Rao Rao merupakan tanah kepunyaan Haji Muhammad Thaib, Haji Adam serta Siti Reno Lila yang merupakan berasal dari suku chaniago Kampuang Dalam dengan penghulunya Datuak Malingka (Idris, 2018). Penamaan masjid juga disesuaikan dengan nama tempat masjid tersebut didirikan yaitu Rao Rao. Dalam pembangunannya, terdapat empat suku yang ikut berkontribusi, yaitu Patapang Kutianyia, Bendang Mandahiling, Bodi Chaniago dan Koto Piliang (Sumalyo, 2000:478).

Masjid ini mulai didirikan pada tahun 1908 M. Sebelum masjid ini didirikan, pada 1907 di daerah ini sudah ada sebuah masjid yang bernama Masjid Usang, akan tetapi berada jauh dari pusat nagari. Oleh karenanya diusulkanlah untuk melakukan pembangunan ulang masjid yang lokasinya berada di dekat keramaian. Pembangunan ulang ini dipelopori oleh Abdurrahman Dt. Marajo Indo. Beliau disebutkan sebagai seorang tokoh adat sekaligus tokoh agama setempat yang disegani oleh pemerintah kolonial Belanda (Syarif, 2017).

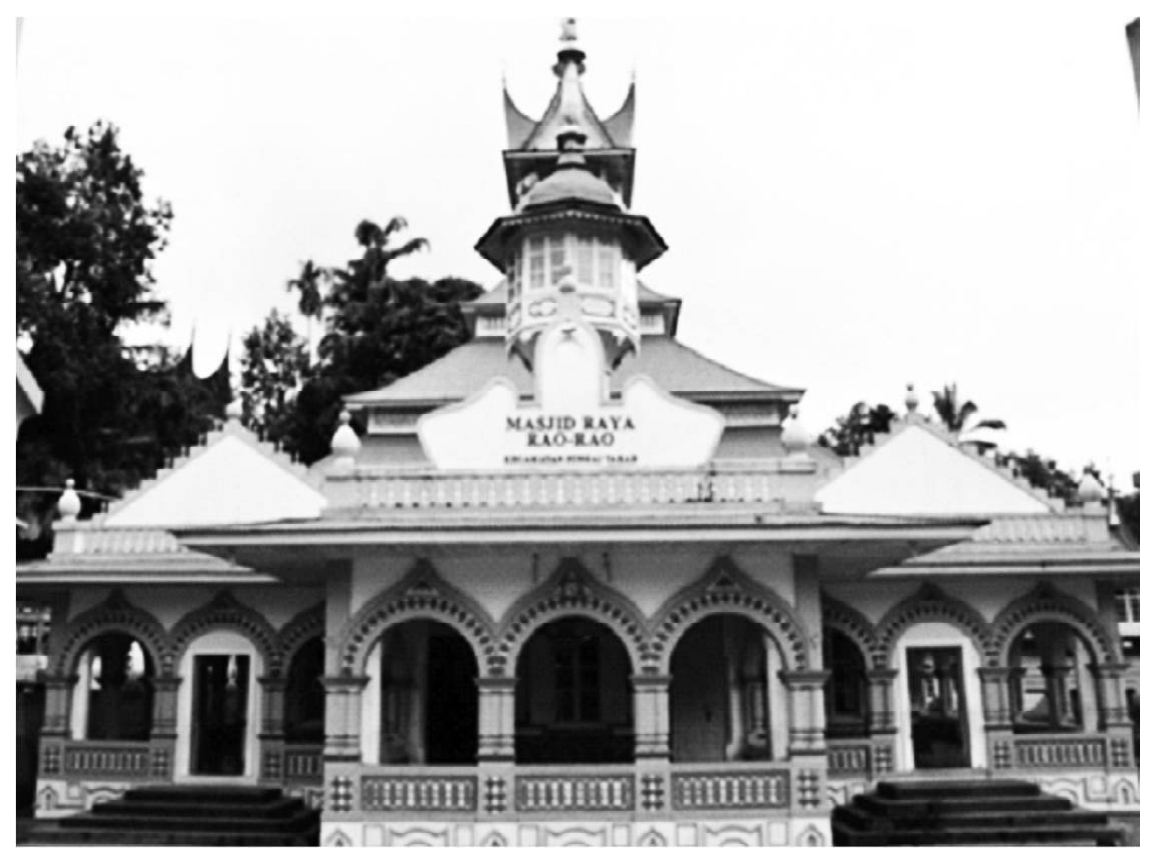

Gambar 1. Masjid Rao Rao (Dokumen: Syahrul, 2017) 
Dalam persiapan pembangunannya, salah seorang pemuka masyarakat, yaitu Dt. Maharajo Indo mengusulkan agar masjid didirikan dengan pusat desa tepatnya di Tobek Sikobua. Setelah disepakati selanjutnya masjid ini dibangun dengan cara bergotong royong. Bahkan para perantau berasal dari Malaysia dan Singapura juga ikut terlibat dalam mengumpulkan dana guna membiayai pembangunan masjid (Sudarman, 2004:68-69). Pembangunan Masjid Rao Rao merupakan kesepakatan dari seluruh perangkat adat dan nagari yang ada saat itu. Selain Abdurrahman Dt. Maharajo Indo, masih terdapat beberapa tokoh lain yang ikut berperan dalam pendirian masjid ini. Tokoh-tokoh tersebut terdiri dari perangkat adat serta perangkat pemerintahan nagari.

Pada masa tersebut Abdurrahman Dt. Maharajo Indo merupakan Penghulu Kepala Rao Rao dari suku Koto Piliang. Selain itu terdapat tokoh lain yang ikut mempelopori pembangunan masjid, yaitu Kajo Inan Parmato Lelo yang saat itu menjabat sebagai sebagai Lareh Rao Rao (Arsip Kesepakatan Pendirian Masjid, 1917). Ia merupakan lareh terakhir yang ada di daerah Rao Rao. Nama-nama tokoh tersebut berada pada daftar perangkat adat yang menandatangani kesepakatan pendirian masjid. Tokoh lain yang terlibat dalam pendirian masjid tersebut diantaranya merupakan penghulu dari empat suku yang ada di Nagari Rao Rao, Imam Adat, Imam Jum'at, Bilal Adat, Bilal Jum'at, Khatib Adat, Kadi Nagari, Manti Adat, serta Hakim Lumbuang. Masjid ini baru mulai difungsikan pada tahun 1918 M, lebih kurang sepuluh tahun setelah dilakukan pembangunan pada tahun $1908 \mathrm{M}$.

Keberadaan Masjid Rao Rao di daerah pedalaman Minangkabau membuat pembangunan berjalan cukup lama. Selain itu melihat bentuk arsitektur yang ada saat ini serta ketersediaan bahan juga menjadi faktor penyebab sehingga pembangunannya membutuhkan waktu. Oleh sebab itu masjid ini baru mulai difungsikan pada tahun $1918 \mathrm{M}$ setelah melalui proses yang panjang semenjak dimulainya pembangunan pada tahun 1908 M. Pembangunannya digagas oleh salah seorang penghulu di daerah Rao Rao, yaitu Abdurrahman Dt. Maharajo Indo serta beberapa tokoh penting yang ada di daerah tersebut.

Melihat bentuk konstruksi bangunan tentu dibutuhkan biaya yang besar untuk membangun masjid. Seperti yang ditulis sebelumnya, biaya pembangunan masjid tidak hanya berasal dari masyarakat setempat, akan tetapi juga melibatkan perantau dalam urusan pembiayaan. Pembangunan masjid ini menelan biaya hingga $f 40.000$ yang berasal dari iuran masyarakat (Suryadi, 2015). 


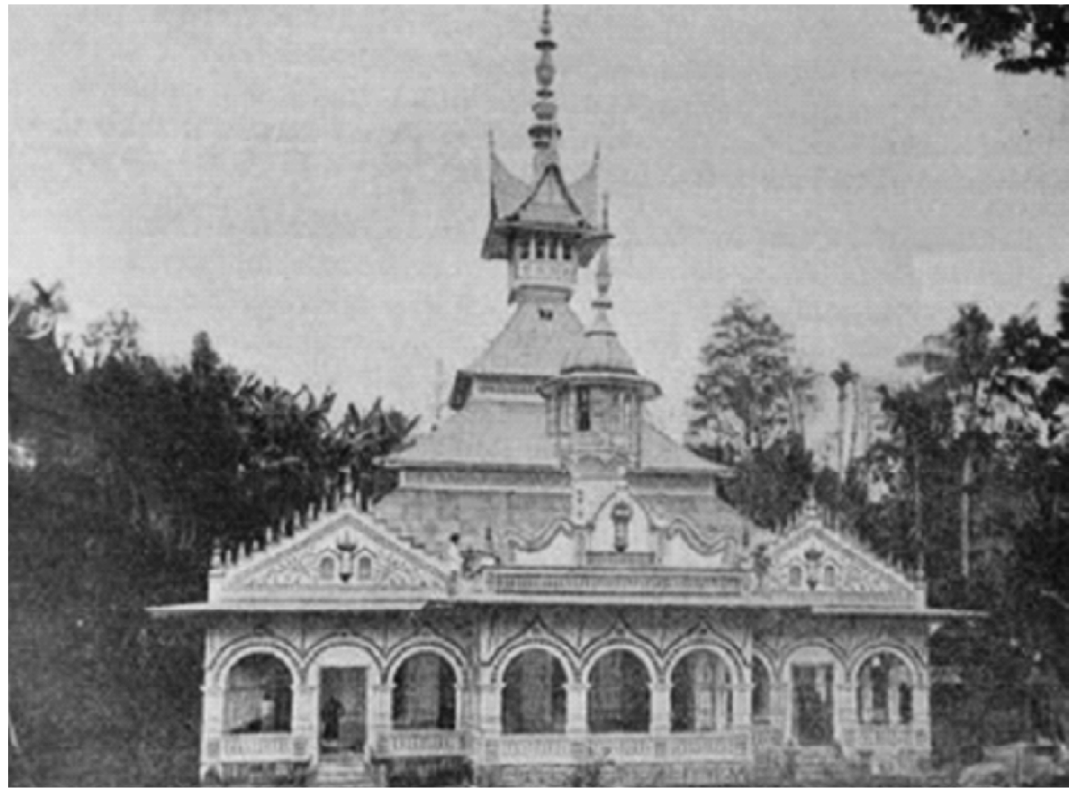

Gambar 2. Masjid Rao Rao Tahun 1924 (Sumber: Suryadi, Mesjid Rao Rao di Kabupaten Tanah Datar). ${ }^{8}$

Semenjak didirikan, masjid ini telah dipugar beberapa kali tanpa merubah bentuk asli. Masjid ini pernah mengalami kerusakan yang cukup berat akibat gempa pada tahun $1926 \mathrm{M}$, akan tetapi tidak disebutkan pemugaran apa saja yang telah dilakukan. Sementara itu pada tahun 1975 M dilakukan pelurusan terhadap menara yang miring (Suryadi, 2015). Pada tahun 1981 M dilakukan pemugaran dengan menambahkan tiang penyangga sebanyak 12 buah di bagian teras masjid. Selanjutnya pada tahun 1992 juga dilakukan pembongkaran tangga menuju loteng atau menara diakibatkan kelapukan bahan. Selain itu pada tahun tersebut juga dilakukan penggantian terhadap beberapa marmer yang pada lantai di dalam bangunan (Idris, 2018).

Sementara itu pada tahun 2007 kembali dilakukan pemugaran terhadap beberapa bagian masjid. Pemugaran tersebut dilakukan setelah terjadinya gempa sehingga menimbulkan kerusakan pada beberapa bagian (BP3 Batusangkar, 2007). Beberapa bagian yang dipugar adalah pembongkaran dan pemasangan loteng papan dan pengecatan yang disesuaikan dengan warna lama. Selain itu juga dilakukan pemasangan les loteng serta perancah ls (BP3 Batusangkar, 2007:34). Terakhir pada tahun 2012 juga dilakukan penggantian terhadap marmer yang ada pada lantai teras di bagian utara masjid (Idris, 2018).

\footnotetext{
${ }^{8}$ Foto tersebut memiliki keterangan "MESDJID RAO-RAO, ONDERAFDEELING BATOESANGKAR (SOEMATERA BARAT). Ongkos memboeat mesdjid itoe lebih dari $f 40.000$, jaïtoe oeang joeran Moeslimin di Rao-rao.” Pernah diterbitkan pada Pandji Poestaka, No. 8, Tahoen II, 21 Februari 1924. Foto ini selanjutnya kembali diulas oleh Suryadi dan diterbitkan pada Harian Umum Singgalang, edisi Lebaran, Juli 2015 dalam rubrik Minang Saisuak dengan judul artikel Mesjid Rao Rao di Kabupaten Tanah Datar.
} 


\section{Akulturasi pada Masjid Rao Rao}

Sebagai masjid yang didirikan pada awal abad 20 M, secara garis besar bangunan Masjid Rao Rao sudah tidak menggunakan kayu sebagai bahan utama dalam pembangunan. Kayu hanya digunakan untuk pembangunan bagian atas bangunan, tepatnya rangka atap hingga menara. Sementara bagian badan bangunan sudah mengunakan bata maupun kapur atau beton sebagai bahan konstruksi.

Penggunaan kontstruksi beton pada fondasi dan tubuh bangunan masjid ini seketika meninggalkan pola bangunan tradisional yang biasanya menggunakan kayu. Pijper menyebutkan bahwa bangunan masjid memiliki kesamaan dengan bangunan candi, mulai dari pondasi tubuh dan atapnya (Pijper, 1974:270). Merujuk pada periode pembangunan masjid ini adalah di era awal abad $20 \mathrm{M}$, diperkirakan pengaruh Hindu Budha tidak lagi sekental pengaruh terhadap bangunan yang dibangun pada masa sebelumnya dan lebih menonjolkan gaya baru dengan menggunakan material beton. ${ }^{9}$

Atap Masjid Rao Rao dibangun berundak berupa limas, pada bagian puncaknya terdapat menara dengan atap gonjong sebanyak empat buah. Selain itu, pada bagian atas tepatnya pada bagian timur atau sisi depan masjid juga terdapat ornamen atap gabel. Gabel ialah atap pelana yang di bagian depannya terdapat dinding (Pratiwo, 2009:94). Atap gabel merupakan salah satu ciri bangunan Belanda. Pada beberapa bagunan Belanda yang tersebar di kawasan Hindia Belanda gabel dipasang pada bagian depan bangunan dengan berbagai bentuk. Gabel terbuat dari bahan beton yang berfungsi untuk menahan angin dan bagian belakangnya disambung dengan atap (Handinoto, 1996:165). ${ }^{10}$ Atap gabel tersebut berbaris sejumlah 3 buah dengan dua bentuk yang berbeda. Satu gabel berbentuk mahkota yang terletak di bagian tengah. Sementara dua lainnya adalah gabel bertingkat yang terletak di sisi kiri dan kanan gabel berbentuk mahkota.

Selain pada bangunan Belanda, gabel juga dipergunakan pada bangunan Cina. Pada bangunan Cina di Indonesia sebelumnya mempergunakan atap gabel hingga kemudian beralih dengan menggunakan bentuk atap miring. Hal tersebut terjadi ketika Belanda mulai menduduki Indonesia dan mulai mendirikan bangunan (Pratiwo, 2009:94). Akan tetapi pada bangunan Cina gabel tidak terletak pada bagian depan bangunan, melainkan pada bagian samping. Penggunaan gabel pada bangunan Cina dapat dilihat pada klenteng.

Pada Masjid Rao-Rao, salah satu gabel berbentuk mahkota. Lazimnya, pada beberapa masjid kuno hiasan mahkota digunakan sebagai hiasan pada bagian kemuncak atap, atau yang biasa dikenal dengan mustaka. Pada bagian ini biasanya mustaka berbentuk mahkota yang distilir (Soekiman, 1996:264). Sedangkan pada beberapa masjid lain mahkota dijadikan atap mimbar, sebagaimana yang terdapat di Masjid Agung Cirebon (Pamungkas, 1996:112). Sementara di Masjid Bingkudu Agam, pola mahkota berada pada bagian atas mimbar, pola mahkota tersebut sudah disesuaikan dengan pola ukiran lokal (Syahrul, 2015:25).

\footnotetext{
${ }^{9}$ Masjid yang dibangun sebelum abad ke $20 \mathrm{M}$ pada umumnya mengunakan kayu sebagai bahan konstruksi.

${ }^{10}$ Beberapa ciri bangunan Belanda antara lain: 1) gevel (gable) pada tampak depan bangunan; 2) tower; 3) dormer; 4) windwijzer (penunjuk angin); 5) nok acroterie (hiasan puncak atap); 6) geveltoppen (hiasan kemuncak atap depan); 7) ragam hias pada tubuh bangunan; dan 8) balustrade.
} 


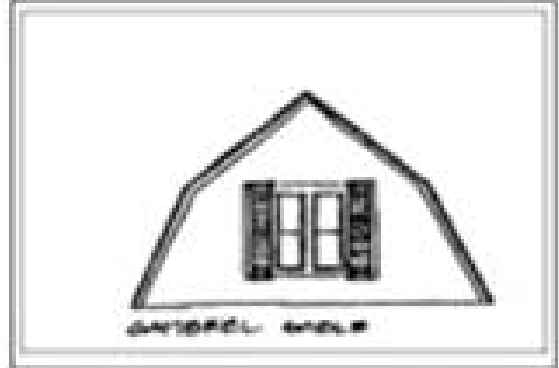

Gambar. 212 . Gamerel Gabe Sumber American vernacuar Desion 280 - 1940 talam kandinotio 1006.16 ?

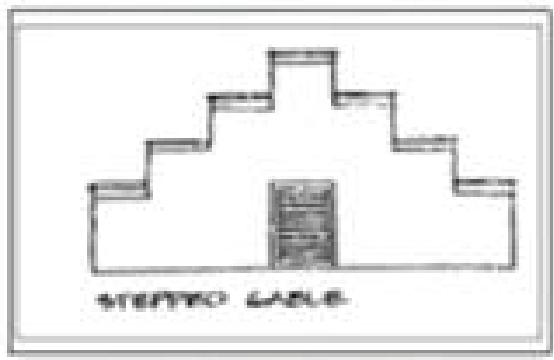

Gambar, 2123 Sresses Gabie Sumber American Vemacisar Deics $1800-1949$ deinm Hondrota, 1996 167

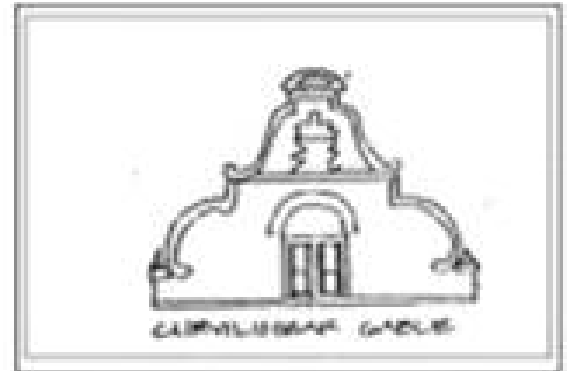

Gamber. 212.2 Cominer beble Sumber: American Verracular Desian $2870-1260$ socam Kandinote. 1926 i6?

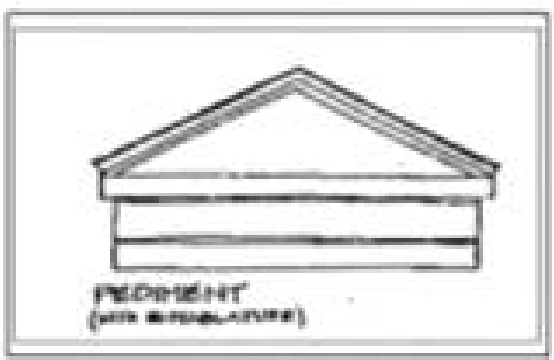

Gamber. 2.12 .4 Pesteert twith enesbiatioel

Sumber Anerican Vemaciar Deig"

Gambar 3. Jenis-jenis Atap Gabel (Handinoto, Perkembangan Kota dan Arsitektur Kolonial Belanda di Surabaya 1870-1940)

Gabel mahkota yang ada saat ini memiliki perbedaan dengan bentuknya pada foto yang diambil pada tahun 1924. Gabel mahkota tersebut memiliki ukuran panjang 4,7 meter dan tinggi 2,58 meter yang terletak di atas parapet berukuran panjang 7,5 meter. Ukuran gabel yang ada saat ini jauh lebih pendek dibandingkan dengan gabel pada gambar lama Masjid Rao Rao. Terjadinya perubahan bentuk dan ukuran pada gabel mahkota tersebut diperkirakan terjadi setelah diambilnya dokumentasi pada tahun 1924 tersebut.

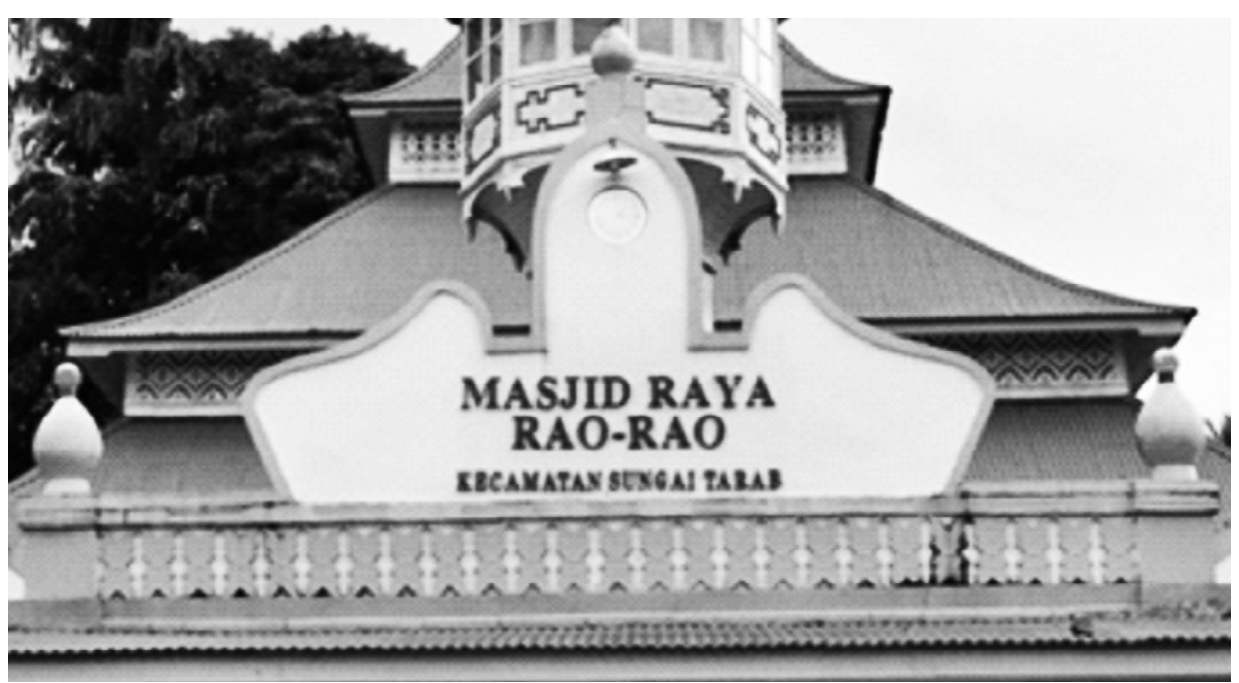

Gambar 4. Mahkota Pada Bagian Depan Masjid Rao Rao

(Dokumen: Syahrul, 2017) 


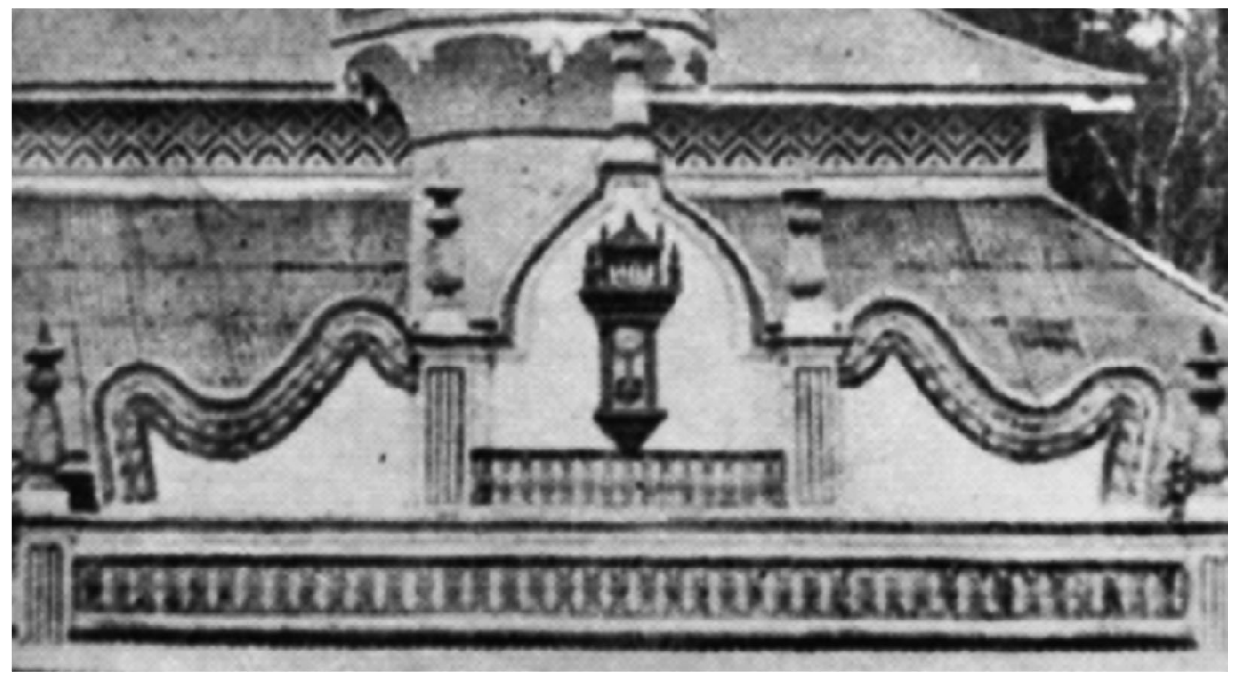

Gambar 5. Ornamen Mahkota pada Foto yang Diambil Tahun 1924, pada Foto ini Terlihat Lima Buah Kemuncak (Sumber: Suryadi, Mesjid Rao Rao di Kabupaten Tanah Datar)

Selain itu perubahan bentuk juga terdapat pada sisi kiri dan kanan gabel. Gabel ini bertingkat dan pada setiap tingkatannya terdapat mustaka atau kemuncak sebagai hiasan. Pada sisi kiri dan kanan serta puncak gabel terdapat kemuncak yang berukuran besar. Sementara pada masing-masing tingkatan terdapat hiasan kemuncak yang berukuran lebih kecil.

Sekalipun demikian, bangunan Masjid Rao Rao tidak mengadopsi bentuk gabel secara keseluruhan. Akan tetapi hanya mengambil bagian dinding temboknya. Sementara bagian atap yang biasanya memanjang di belakang gabel tidak dipergunakan. Ornamen yang terdapat pada bagian mahkota dan gabel di Masjid Rao Rao sudah tidak sama dengan ornamen ketika masjid ini didirikan. Pada foto yang diambil pada tahun 1924 pada bagian tersebut terdapat beberapa ornamen serta ragam hias. Sementara saat ini ragam hias tidak lagi ditemukan gabel tersebut.

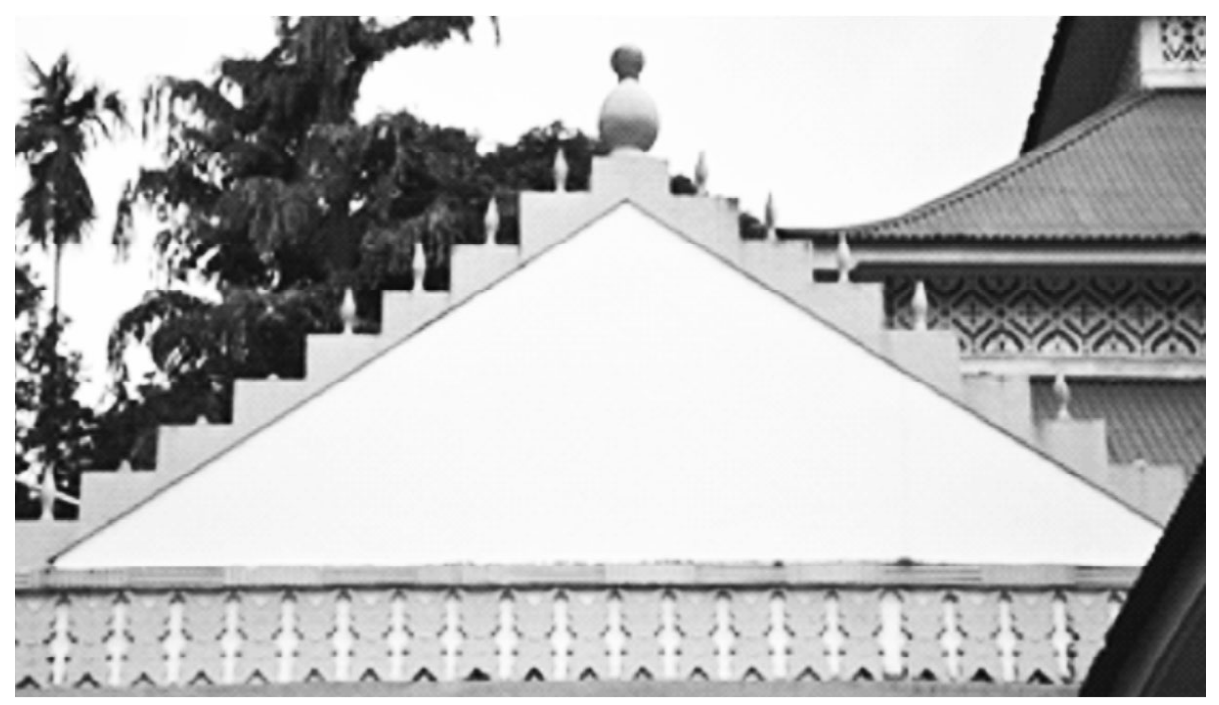

Gambar 6. Gabel Pada Bagian Depan Masjid Rao Rao

(Dokumen: Syahrul, 2017) 
Pada ornamen kemuncak, sebelumnya memiliki bentuk yang serupa kemuncak di atap masjid dengan bahan dari beton. Akan tetapi saat ini ornamen tersebut hanya berupa kemuncak biasa dan ukurannya lebih pendek dari pada kemuncak sebelumnya. Dari segi jumlah, kemuncak tersebut tidak lagi sama jumlahnya dengan jumlah kemuncak saat ini.

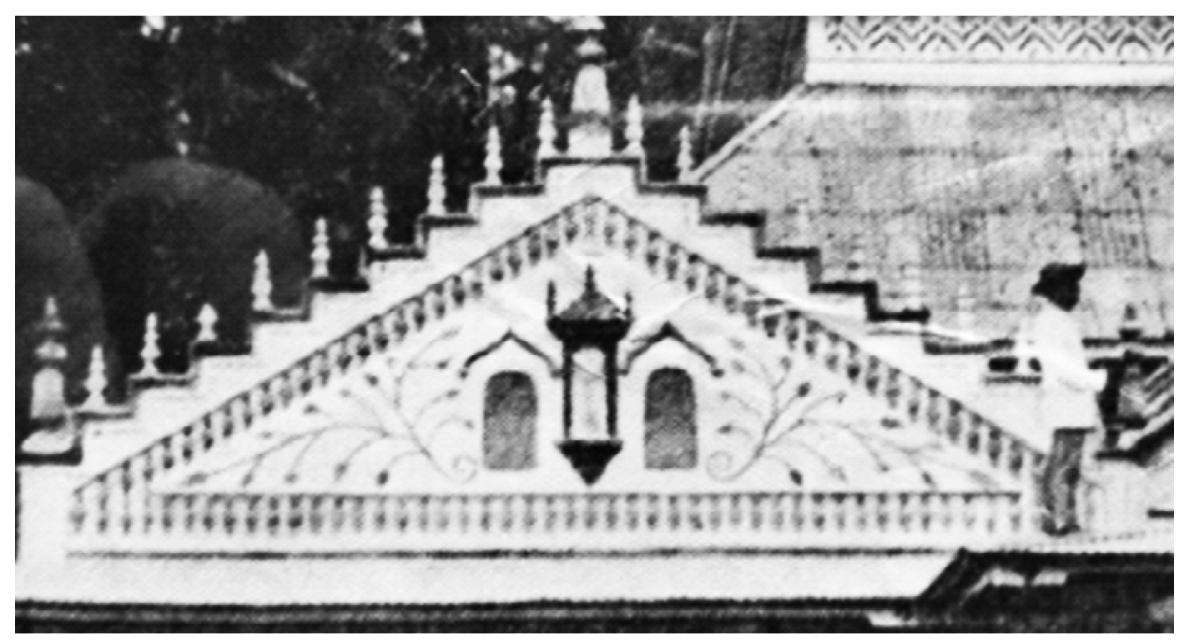

Gambar 7. Ornamen dan Ragam Hias Gabel Pada Foto yang Diambil pada Tahun 1924 (Sumber: Suryadi, Mesjid Rao Rao di Kabupaten Tanah Datar)

Sebelumnya kemuncak berjumlah 11 buah, sementara saat ini hanya berjumlah 9 kemuncak. Pada saat dibangun, pada bagian dua buah gabel di sisi kiri dan kanan mahkota terdapat 6 kemuncak yang masing-masingnya memiliki tiga kemuncak. Sedangkan pada bagian gabel yang berbentuk mahkota terdapat lima kemuncak, sementara saat ini hanya ditemukan 3 kemuncak pada bagian tersebut, artinya terdapat dua ornamen kemuncak yang hilang.

Pada gabel di sisi kiri dan kanan, sebelumnya terdapat ornamen berupa lampu hias yang ditempel pada bagian tengahnya. Di sisi kiri dan kanan ornamen tersebut dihiasi dengan motif hiasan berbentuk floral. Sementara saat itu bagian gabel mahkota juga memiliki lampu hias yang dipasang pada dinding di bagian tengahnya. Akan tetapi pada bagian ini tidak terdapat ragam hias, kecuali di bawah lampu hias terdapat sebuah parapet tambahan yang ukurannya lebih pendek dari pada parapet yang ada saat ini.

Beberapa ornamen dan ragam hias tersebut saat ini sudah tidak ditemukan pada bagian tersebut. Kapan dan penyebab hilangnya bagian tersebut juga tidak diketahui secara pasti. Sebab tidak ditemukan sumber-sumber yang menceritakan riwayat renovasi masjid secara detail.

Penggunaan gabel pada bangunan masjid ini jelas telah mengadopsi bentuk arsitektur asing. Gabel yang dibangun pada bagian depan bangunan mengadopsi bentuk penggunaan gabel pada bangunan Belanda. Selain itu gabel berbentuk tingkatan yang terdapat pada sisi kiri dan kanan juga merupakan salah satu bentuk gabel yang ada pada bangunan Belanda.

Bagian lain yang juga mendapatkan pengaruh dari interaksi budaya lokal dan budaya Eropa adalah pada bagian pintu dan jendela masjid yang berukuran besar. Masjid Rao Rao memiliki 4 buah pintu kayu berdauan dua. Satu pintu berada di tengah-tengah bagian utara dan satu pintu lagi berada di tengah-tengah bagian selatan masjid. sementara itu dua pintu lagi berada di bagian selatan bangunan masjid Rao Rao. Pintu-pintu tersebut memiliki ukuran tinggi $2.5 \mathrm{~m}$ dan lebar $0.9 \mathrm{~m}$. 


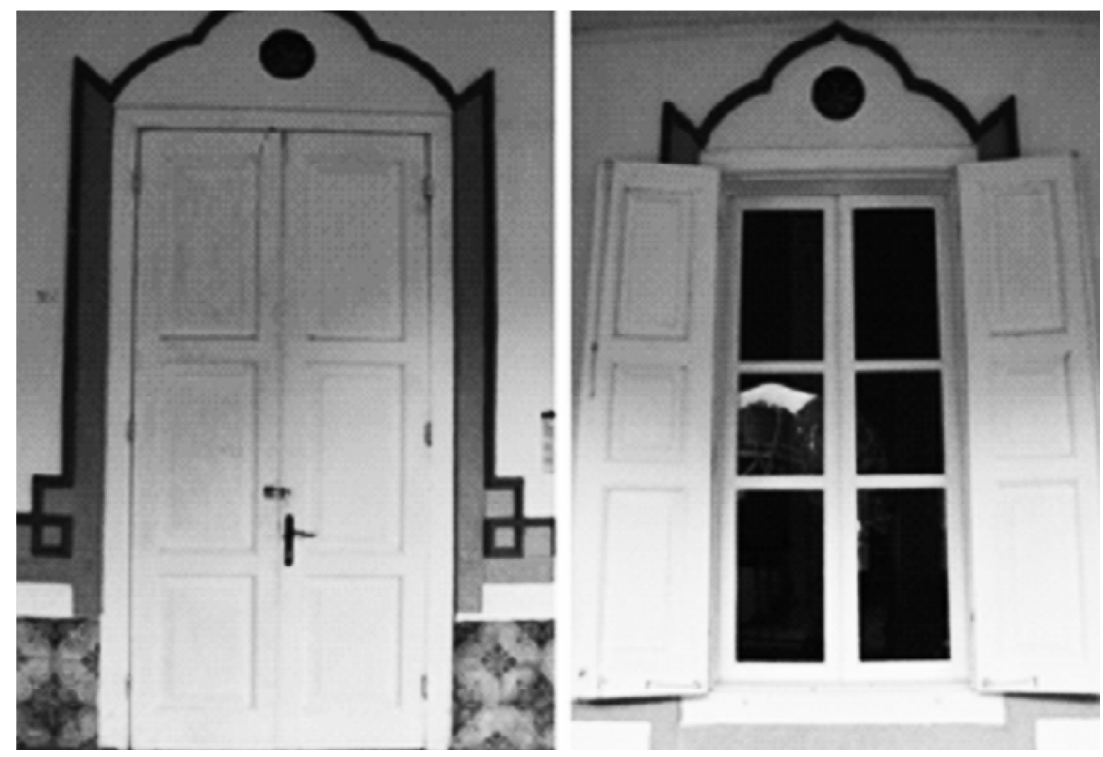

Gambar 8. Pintu dan Jendela Masjid Rao Rao

(Dokumen: Syahrul, 2017)

Jendela pada masjid ini berjumlah 13 buah. 2 buah jendela terdapat pada bagian mihrab atau bagian timur masjid. Empat jendela berada di sisi utara bangunan dan empat jendela lagi berada pada sisi selatan bangunan masjid. Tiga pintu lainnya berada pada bagian barat masjid dengan posisinya diselingi oleh dua buah pintu. Deskripsi arkeologis jendela tersebut adalah pada bagian yang terbuka ke luar terdapat jendela kayu berdauan dua. Pada bagian yang terbua ke bagian dalam masjid terdapat jendela kaca yang juga berdaun dua. Jendela-jendela ini berbentuk polos tanpa memiliki motif hias maupun ornamen khusus di setiap bagiannya. Akan tetapi pada bagian atas atau ambang pintu dan jendela dihiasi dengan motif kaligrafi. Ayat serta jenis khath yang termuat dalam kaligrafi tersebut berbeda antara satu sama lain.

Ukuran pintu dan jendela yang cukup besar memperlihatkan pengaruh Arsitektur Eropa pada pembangunan masjid. Salah satu ciri dari bangunan Indis ${ }^{11}$ yang ada pada awal abad XX M adalah jendela-jendela yang luas dan tinggi (Soekiman, 1996:120). Selain itu penggunaan jendela dan pintu dalam ukuran besar juga dapat ditemui pada beberapa bagunan peninggalan kolonial yang ada di Indonesia.

Selanjutnya pengaruh Eropa juga terdapat pada penggunaan keramik pada mimbar. Pengaruh yang terdapat pada bagian ini bukan dari sisi bentuk atau rupa mimbar, akan tetapi pada sisi penggunaan keramik yang diproduksi oleh Eropa. Mimbar yang terdapat pada masjid ini tidak jauh berbeda dengan mimbar pada masjid lainnya. Akan tetapi Mimbar masjid RaoRao memiliki keunikan karena sebagian besar bidangnya dilapisi oleh pecahan keramik atau porselen.

${ }^{11}$ Kata-kata Indis pada dasarnya merupakan perpaduan antara budaya kolonial dengan budaya lokal Jawa. Pada bagian ini gaya bangunan maupun perilaku masyarakat lokal membaur denga kebudayaan eropa. Sekalipun dua kebudayaan ini saling mengisi, akan tetapi masing-masing kebudayaan tetap memperlihatkan ciri khas masingmasing sekalipun dalam satu bangunan. 
Pada bagian tengah mihrab, terdapat sebuah mimbar yang terbuat dari batu. Sebagai sebuah simbol, mimbar juga memilki nilai sakral tersendiri, salah satunya adalah terkait orang yang dapat naik ke atas mimbar tersebut hanyalah orang-orang tertentu. Setidaknya terdapat dua bentuk mimbar yang ada di Minangkabau. Pertama adalah mimbar yang terbuat dari kayu atau tembok dan pada bagian depannya terdapat tangga dan tanpa ditutupi oleh penghalang, biasanya mimbar ini terdapat pada masjid klasik. Sementara yang kedua adalah mimbar yang terbuat dari kayu dan di depannya terdapat penghalang dengan tangga naik ada di bagian belakang mimbar, pada umumnya masjid modern menggunakan mimbar serupa ini (Sudarman, 2013:49).

Mimbar ini sudah dibangun secara permanen pada tahun 1930 (Sudarman, 2004:70). Mimbar tersebut memiliki ukuran 3 x $1.38 \mathrm{~m}$ dengan tingi $3.15 \mathrm{~m}$. Untuk mencapai bagian atas mimbar terdapat lima buah anak tangga. Sementara itu bagian depan mimbar pada bagian tangga paling bawah terdapat gapura yang bagian atasnya berbentuk pelengkung. Pemasangan keramik pada mimbar ini seiring dengan pembuatan mimbar, yakni pada tahun 1930. Pecahan keramik tersebut bukan sengaja dipecahkan, akan tetapi keramik-keramik tersebut pecah saat terjadinya gempa pada tahun 1926. Pecahan keramik tersebut merupakan kepunyaan keluarga Haji Mutahhib (Makhfuz Idris, 2018).

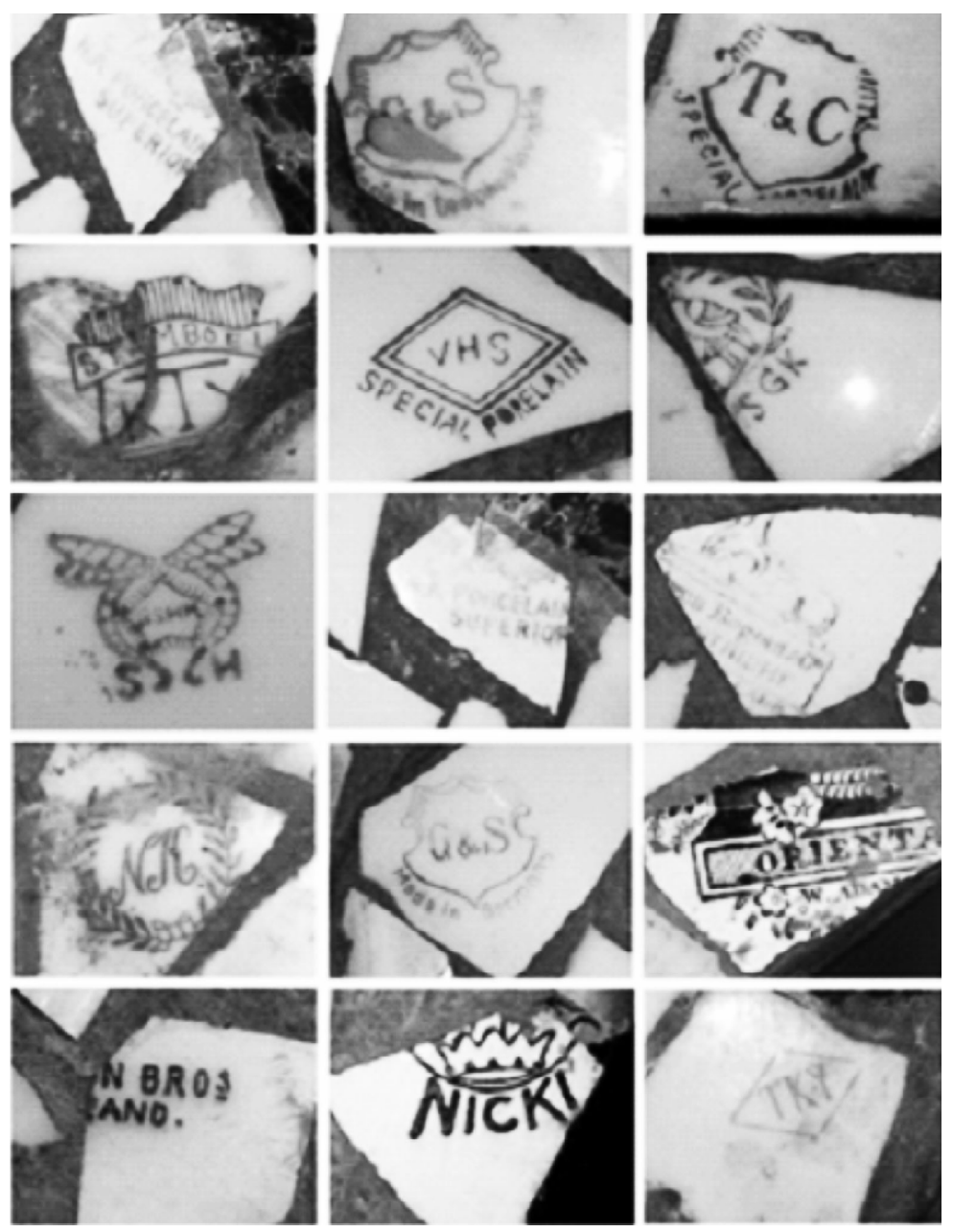

Gambar 9. Ornamen Keramik Eropa Pada Mimbar Masjid Rao Rao (Dokumen: Syahrul, 2017) 
Keramik-keramik tersebut merupakan produksi beberapa negara. Sebagaimana yang diulas pada bagian mimbar sebelumnya, keramik-keramik tersebut memiliki warna yang mencolok. Selain itu pecahan keramik tersebut juga memiliki motif yang beragam yang ditempel secara acak sehingga membentuk pola-pola tertentu. Kaca keramik tersebut berwarna-warni dan terlihat begitu mencolok. Sangat sulit untuk mengidentifikasi bentuk motif tersebut karena sudah menjadi potongan-potongan yang terpisah.

Akan tetapi beberapa bagian masih dapat diidentifikasi. Dari beberapa potongan diketahui bahwa keramik yang dipergunakan merupakan keramik yang diproduksi oleh beberapa negara di Eropa serta Cina. Beberapa keramik merupakan produksi Eropa diantaranya adalah G \& P yang merupakan produksi Jerman, selain itu masih terdapat beberapa merek lain seperti VHS, KTV, SGK, BSHM, NK, Oriental, NICKI dan TKY. Selain itu juga terdapat beberapa keramik Cina yang tidak diketahui jelas nama pabrik tempat memproduksinya.

Bagian lain yang juga menggunakan bahan dari Eropa adalah marmer pada bagian lantai masjid. Selain pada bagian dalam bangunan, teras atau selasar masjid ini juga dihiasi oleh lantai marmer bermotif bunga coklat yang didatangkan dari Belanda (BP3 Batusangkar, 2005:9). Setelah selesai dibangun, lantai masjid ini masih belum menggunakan marmer. Oleh sebab itu maka para pemuka nagari berangkat ke Malaysia untuk mencari sumbangan dana. Setelah dana yang dibutuhkan terkumpul, maka langsung dilakukan pemesanan marmer ke Eropa, tepatnya Italia (Idris, 2018).

Marmer yang digunakan pada masjid ini adalah marmer kualitas kedua dari tiga tipe kualitas yang ada. Setelah dipesan, marmer langsung dikirim menuju Sumatera dengan menggunakan kapal dan berlabuh di Teluk Bayur. Selanjutnya marmer diangkut dengan menggunakan Kereta Api menuju Payakumbuh dan diturunkan di daerah Piladang. Kemudian marmer baru dibawa ke Rao Rao dengan menggunakan pedati (Makhfuz Idris, 2018).

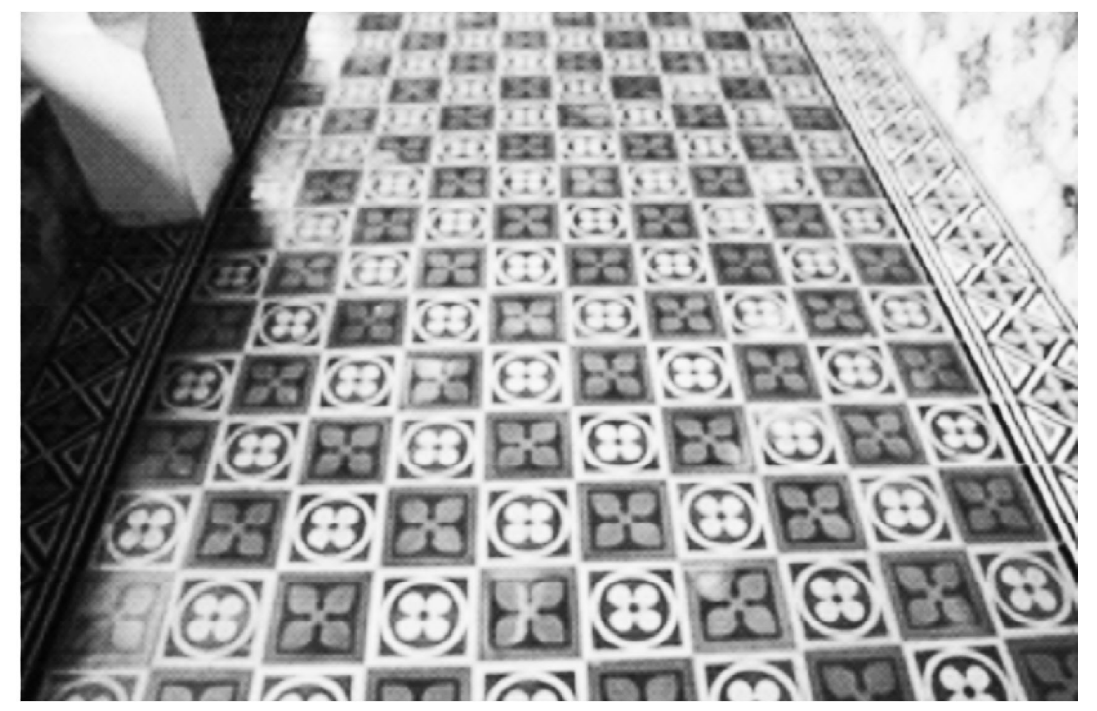

Gambar 10. Lantai Teras Masjid Rao Rao

(Dokumen: Syahrul, 2017) 


\section{PENUTUP}

Di Minangkabau atau khususnya di Tanah Datar, Islam bukanlah satu-satunya kebudayaan asing yang pernah bersentuhan dengan masyarakat lokal. Selain Islam yang begitu melekat dalam kehidupan masyarakat, masih ada beberapa kebudayaan telah juga pernah mengakar di tengah-tengah masyarakat. Kebudayaan tersebut ialah kebudayaan Hindu-Budha, Cina serta kebudayaan Eropa yang masuk melalui kolonialisasi.

Keragaman budaya yang mendiami tanah Minangkabau selanjutnya saling mempengaruhi antara satu sama lain. Dalam mendirikan masjid misalnya, bangunan masjid yang ada di Minangkabau bukanlah masjid dengan gaya arsitektur Islam tempat dimana agama tersebut berasal. Akan tetapi Masjid yang didirikan di Minangkabau, terutama di Tanah Datar mengakomodasi segala kebudayaan yang ada tanpa meninggalkan nilai-nilai keislaman dalam bentuk arsitekturnya.

Proses akulturasi budaya tidak hanya terjadi dalam bentuk perilaku, akan tetapi juga terjadi pada benda yang menjadi hasil kebudayaan. Masjid Rao Rao Tanah Datar adalah salah satu dari banyak masjid yang menyimpan kebudayaan Eropa dalam wujud arsitekturnya. Hal tersebut membuktikan bahwa Islam yang berkembang di Tanah Datar serupa dengan Islam yang berkembang di wilayah lain di Indonesia, yaitu berbaur dengan kebudayaan lain sehingga memberikan wujud baru dalam corak Islam di Minangkabau. Hal tersebut selanjutnya menjadi identitas berupa kearifan lokal yang menjadi ciri khas daerah tersebut.

Terjadinya akluturasi pada bangunan masjid ini tentu tidak terlepas dari keberadaan masyarakatnya. Akulturasi yang terjadi membuktikan masyarakat Tanah Datar, khususnya masyarakat Rao Rao adalah masyarakat yang terbuka dengan berbagai kebudayaan. Dikatakan demikian lantaran masuknya kebudayaan non-Islam ke dalam arsitektur masjid yang merupakan tempat sakral bagi umat Islam. Dalam hal ini memperlihatkan betapa masyarakat Tanah Datar yang pada dasarnya berada di pedalaman Minangkabau memiliki keterbukaan terhadap berbagai kebudayaan.

Keberadaan Masjid Rao Rao semakin memperkuat identitas keislaman umat muslim di Nusantara. Perpaduan berbagai kebudayaan asing dalam bangunan masjid merupakan identitas tersendiri bagi Islam di daerah tersebut. Berbagai kebudayaan tersebut menjadi sebuah kebudayaan baru sebagai sebuah kerifan lokal dan menjadi bagian dari corak keislaman Nusantara.

\section{DAFTAR PUSTAKA}

Amran, Rusli. 1981. Sumatera Barat Hinga Palakat Panjang. Jakarta: Sinar Harapan.

Arsip kesepakatan Tokoh Masyarakat Rao Rap tentang pendirian masjid bertanggal 20 September 1917.

Balai Pelestarian Peninggalan Purbakala Batusangkar Wilayah Kerja Provinsi Sumatera Barat, Riau dan Kepulauan Riau. 2005. Masjid-masjid Kuna di Sumatera Barat, Riau dan Kepulauan Riau.

Balai Pelestarian Peninggalan Purbakala Batusangkar. 2007. Laporan Pelaksanaan Kegiatan Dana Destinasi Sumatera Barat Untuk Bantuan Bencana Gempa Bumi dan Kebakaran Istana 
Pagaruyuang. Batusangkar: Balai Pelestarian Peninggalan Purbakala Batusangkar Wilayah Kerja Sumatera Barat, Riau dan Kepulauan Riau.

Dihoeloe, L Dt R. 1939. Riwayat Perjuangan Tuanku Imam Bonjol. Medan: Boekhandel Islamijah.

Geertz, Clifford. 1983. Abangan, Santri, Priyayi dalam Masyarakat Jawa. Jakarta: Pustaka Jaya.

Handinoto. 1996. Perkembangan Kota dan Arsitektur Kolonial Belanda di Surabaya 1870-1940. Yogyakarta: Andi Offset.

Junaidi. 2004. Masjid Raya Rao Rao. Padang: Pusaka.

Keesing, Roger M. Terj. Samuel Gunaan. 1999. Antropologi Budaya Suatu Perspektif Kontemporer. Jakarta: Erlangga.

Koentjaraningrat. 2000. Pengantar Ilmu Antropologi. Jakarta: Rinneka Cipta.

Makhfuz Idris Datuak Rajo Nan Paik, Tokoh masyarakat Nagari Rao Rao, Wawancara Pribadi, Rao Rao, Januari 2018.

Murtomo, Adji. 2008. “Arsitektur Kolonial Kota Lama Semarang”, dalam Jurnal Enclosure, Volume 7 No. 2 Juni Tahun 2008

Navis, A.A. 1984. Alam Terkembang Jadi Guru. Jakarta: Grafiti Press.

Pamungkas, Dharmawanti Dewi. 1996. Seni Rupa Islam Pada Gaya Arsitektur dan Interior Masjid Agung Yogyakarta Awal Abad XX. Yogyakarta: Tesis UGM.

Pijper, G.F. 1974. The Minaret In Java. Leiden: E.J Bill.

Pratiwo, 2009. "Mencari Semangat Zaman, Arsitektur Cina di Indonesia", dalam buku Masa Lalu Dalam Masa Kini Arsitektur Indonesia. Jakarta: Gramedia, 2009.

Prijotomo, Josef. 2008. Pasang Surut Arsitektur Indonesia. Surabaya: Wastu Lanas Grafika.

Rahmat, Syahrul. 2015. "Pengaruh Adat Terhadap Arsitektur Masjid di Luhak Nan Tigo", dalam buletin Arkeologi Amoghapasa Edisi 19 Tahun 2015.

Shamad, Irhash. A. 2003. Ilmu Sejarah. Jakarta: Hayfa Press.

Soekiman, Djoko. 1996. Kebudayaan Indis dan Gaya Hidup Masyarakat Pendukungnya di Jawa. Yogyakarta: Disertasi Universitas Gajah Mada.

Sudarman. 2014. Arsitektur Masjid di Minangkabau Dari Masa ke Masa. Padang: Imam Bonjol Press.

Sudarman. 2013. Arsitektur Rumah Ibadah Kuno di Minangkabau oleh Sudarman. Draft Hasil Penelitian, Belum diterbitkan,.

Sumalyo, Yulianto. 2000. Arsitektur Masjid dan Bangunan Sejarah Muslim. Yogyakarta: Gajah Mada University Press.

Suryadi. 2015. "Mesjid Rao Rao di Kabupaten Tanah Datar". dalam rubrik Minang Saisuak, Singgalang. Juli.

Syarif, Marjohan. 2017. Laporan Pemutakhiran Data Masjid Rao Rao. Batusangkar: Balai Pelestarian Cagar Budaya Batusangkar Wilayah Kerja Sumatera Barat, Riau dan Kepulauan Riau.

Waluyo, Eddy Hadi. 2013. "Akulturasi Budaya Cina Pada Arsitektur Masjid Kuno Di Jawa Tengah" dalam Jurnal Desain Vol.1 No. 1, 2013.

Wuisman, Jan J.J.M. 2009. "Masa Lalu Dalam Masa Kini, Posisi dan Peran Tradisi-Tradisi Vernekular Indonesia dan Langgam Bangunan Masa Lalu Dalam Masa Kini”, dalam buku Masa Lalu Dalam Masa Kini Arsitektur Indonesia. Jakarta: Gramedia, 2009.

Zulqayyim. 2006. Bukittinggi Tempo Doeloe. Padang: Andalas University Press. 